\title{
Identification of Potential Landslide Susceptible Area in the Lesser Himalayan Terrain of Nepal
}

\author{
Kismat Pokhrel11, Bharat Prasad Bhandari1,2* \\ ${ }^{1}$ Goldengate International College, Tribhuvan University, Kathmandu, Nepal \\ ${ }^{2}$ Central Department of Environment Science, Tribhuvan University, Kathmandu, Nepal \\ Email: ^bbhandari@cdes.edu.np
}

How to cite this paper: Pokhrel, K., \& Bhandari, B. P. (2019). Identification of Potential Landslide Susceptible Area in the Lesser Himalayan Terrain of Nepal. Journal of Geoscience and Environment Protection, 7, 24-38.

https://doi.org/10.4236/gep.2019.711003

Received: October 30, 2019

Accepted: November 8, 2019

Published: November 11, 2019

Copyright $\odot 2019$ by author(s) and Scientific Research Publishing Inc. This work is licensed under the Creative Commons Attribution International License (CC BY 4.0).

http://creativecommons.org/licenses/by/4.0/

\begin{abstract}
Landslide susceptibility mapping is a very important tool to identify potential landslide-prone areas. In this work, weight of evidence method is applied to obtain landslide susceptibility assessment. Weight of evidence model is commonly applied in the landslide study as it is widely acceptable and easy to use. The objective of this paper is to prepare the landslide susceptibility map of Lung Khola catchment, Pyuthan District of Nepal. Altogether, 84 landslides were identified after landslide inventory. The thematic layers of all causative factors and existing landslides are prepared in Arc GISsoftware. Mainly, Digital Elevation Model (DEM) based causative factors and field data were used to prepare the data layers of the causative factors. In this research, 8 intrinsic factors were used for the landslide assessment. South East and East facing aspects, slope $>60$ degrees, elevation ranges $1300-1700 \mathrm{~m}$, phylitic rocks and agricultural land followed by forest are the major contributors of landslide hazard in the study area. The weight of evidence model was validated by using area under curve method. The success rate curve showed the accuracy of $73.16 \%$. It can be concluded that weight of evidence model is suitable model for landslide susceptibility analysis and the area is highly susceptible to landslide occurrence.
\end{abstract}

\section{Keywords}

Weight of Evidence, Landslide Modeling, Bivariate Method, DEM

\section{Introduction}

Landslides are common phenomenon among the natural hazards that occur regularly in Nepal. Landslide claims many human lives every year and causes 
other damages such as destruction and blockages of highways, losses of livestock, crops, and agricultural land. Based on a reconnaissance study, Laban (1979) estimated that at least 75 percent of all landslides in Nepal were natural. But in the present situation, landslides can be induced by either natural or human factors, or both. Some natural factors that contribute to landslides are high relief or steep slopes, unstable geology, and concentrated rainfall. Human factors can be deforestation, improper land use and construction, and agricultural activities on hill slopes. Lithostratigraphy contributes to erosion and landslide (Bhandari \& Dhakal, 2018). Other factors that lead to landslide are toe cut of the hill, over saturation of sediment, earthquakes or blasting are as well as the factors that lead to low shear strength such as weak soil, high pore-water pressure, and so on. Earthquakes and heavy rainfall trigger the landslide in most cases. Landslides often give rise to debris flows. A debris flow has enormous energy which causes widespread damage to physical structures like bridges and hydroelectric power stations on its way downstream. Potential sites that are prone to landslide should, therefore, be identified to reduce the damage caused by disaster.

Landslide susceptibility assessment aims to differentiate a land surface into homogeneous areas according to their probability of failure caused by mass movement at specific location (Varnes, 1978). Physically based landslide susceptibility model can perform at the same time temporal and spatial forecasting of landslides which can define when and where a landslide will occur (Baum et al., 2002, 2010; Crosta \& Fratini, 2003; Guzzetti et al., 2000; Lepore et al., 2013; Rosi et al., 2013) but according to Brabb (1985), susceptibility maps are used to assess where a landslide should be expected, they do not contain any temporal information about when a landslide will occur. The susceptibility map can be prepared in a GIS using statistical, heuristic or physically-based methods (Guzzetti et al., 2005). With heuristic methods, weights are assigned to the predisposing factors also known as causative factors or evidence layers, based on the experience of the experts, whereas in data-driven statistical techniques, weights are obtained by correlating landslide occurrences and evidence layers, using both bivariate and multivariate methods. Commonly used bivariate methods are information value and weights of evidence modeling in which weights for each parameter are derived from the landslide inventory (Mathew et al., 2007). The weights-of-evidence model has many advantages compared to other statistical methods. Weights-ofevidence is a data-driven method that is basically the Bayesian approach in a log-linear form using prior and posterior probability and is applied where sufficient data are available to estimate the relative importance of evidential themes by statistical means (Bonham-Carter, 1994).

The families displaced by last year's (June 2016) landslide at Phopli area in Naubahini Rural Municipality, Pyuthan of Nepal, are still vulnerable to landslides. It is necessary to identify geologically and environmentally safe site for building the proposed settlement and it is also important to identify vulnerable community of landslide prone areas. Site investigation and consultation with community is necessary to figure out landslide susceptible areas in Naubahini Rural Mu- 
nicipality. The main objective of this study is to prepare the landslide susceptibility map of Phopli area (Naubahini Rural Municipality) of Pyuthan district of Nepal. Department of Mines and Geology, Government of Nepal has prepared the detail geological map of this area in $2011 \mathrm{AD}$ but study related to landslide is still lacking in this area. Preparation of landslide susceptibility map is new work and the result obtains from this work will be applicable for local government to prepare land use plan of this area.

\section{Materials and Methods}

\subsection{Study Area}

Study area (Figure 1(a) \& Figure 1(b)) includes Lung Khola catchment in Naubahini Rural Municipality which lies in Pyuthan district of Nepal. The study area is located at longitude from $82^{\circ} 49^{\prime} \mathrm{E}$ to $82^{\circ} 56^{\prime} \mathrm{E}$ and Latitude of $28^{\circ} 9^{\prime} \mathrm{N}$ to $28^{\circ} 16^{\prime} \mathrm{N}$. Elevation in study area ranges from $800 \mathrm{~m}$ to $2462 \mathrm{~m}$ mean above sea level. The area is bounded by the Rolpa district at North and JhimrukKhola at South. Lung Khola meets Jhimruk River at Damti. Major portion of the Naubahini Rural Municipality belongs to the Fore Himalaya physiographic region and Mahabharat range. Key landform development process of this physiographic region is tectonic upliftment, weathering, erosion, sediment deposition and slope failure (Upreti, 2001). This area is vulnerable for large landslide occurrences because of less soil and steep slopes, presence of weak rocks like: phyllite, limestone, weathered slate, etc. that exhibit frequent rock failure, sliding, rupture (Dahal et al, 2012). Most slopes are south facing and gradient ranges from $0^{\circ}$ to $77.5^{\circ}$.

\subsection{General Geology}

Geologically, Lung Khola watershed and Naubahini Rural Municipality lies on lesser Himalayan sequence, Mahabharat Range and Hilly Region. The part between downstream at Damti to Upper part in upper Damri, there is a presence of Robang Phyllite, White Quartzite, Dhading Dolomite, Malekhu Limestone, Norpul Formation, Alluvial Deposit, Coloristic Gneiss (DMG, 2006). Higher elevation of study area is prone to landslide as a long thrust passes through it.

\section{Methods}

\subsection{Data Preparation}

High resolution imagery of Google earth (Imagery date October 2017) was used as the primary sources for the landslide inventory map. A digitized map of the landslide boundaries was produced with the visual interpretation of Google Earth Imagery. Landslides including the scars and deposits area were converted to polygons. The digital data having landslide polygons were imported to Arc GIS 10.2 for analysis. Landslide Polygons were projected to Transverse Mercator with $82^{\circ}$ east from central meridian (datum level of WGS 1984). This projection system was applied to all the database of study area. Then vector to raster conversion was undertaken to provide a raster data of landslide areas with $12.5 \mathrm{~m}$ cell size (DEM). 


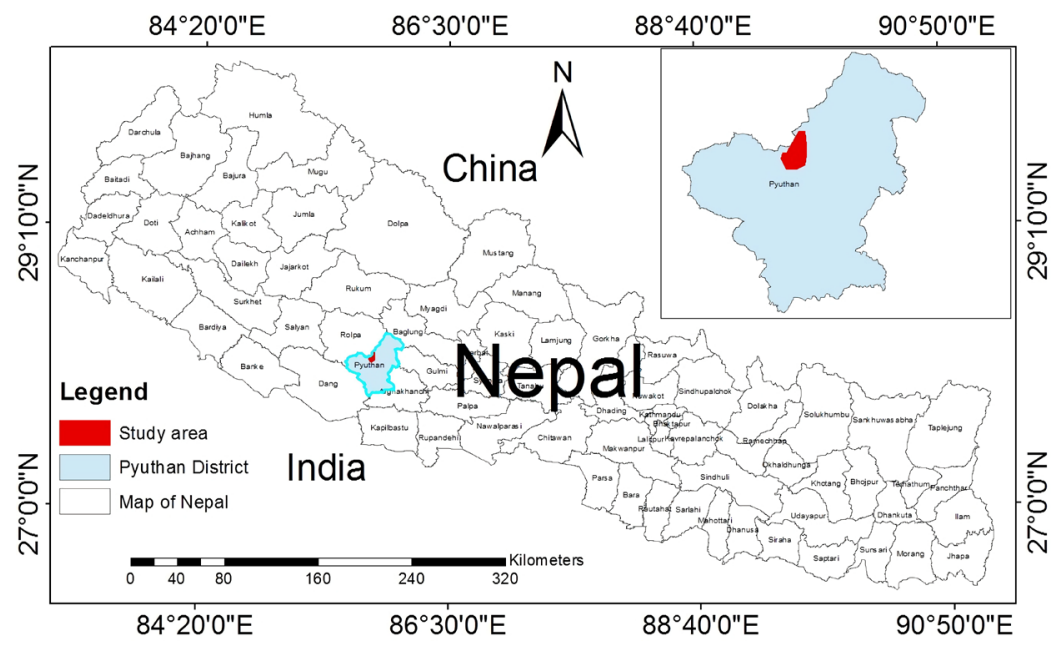

(a)

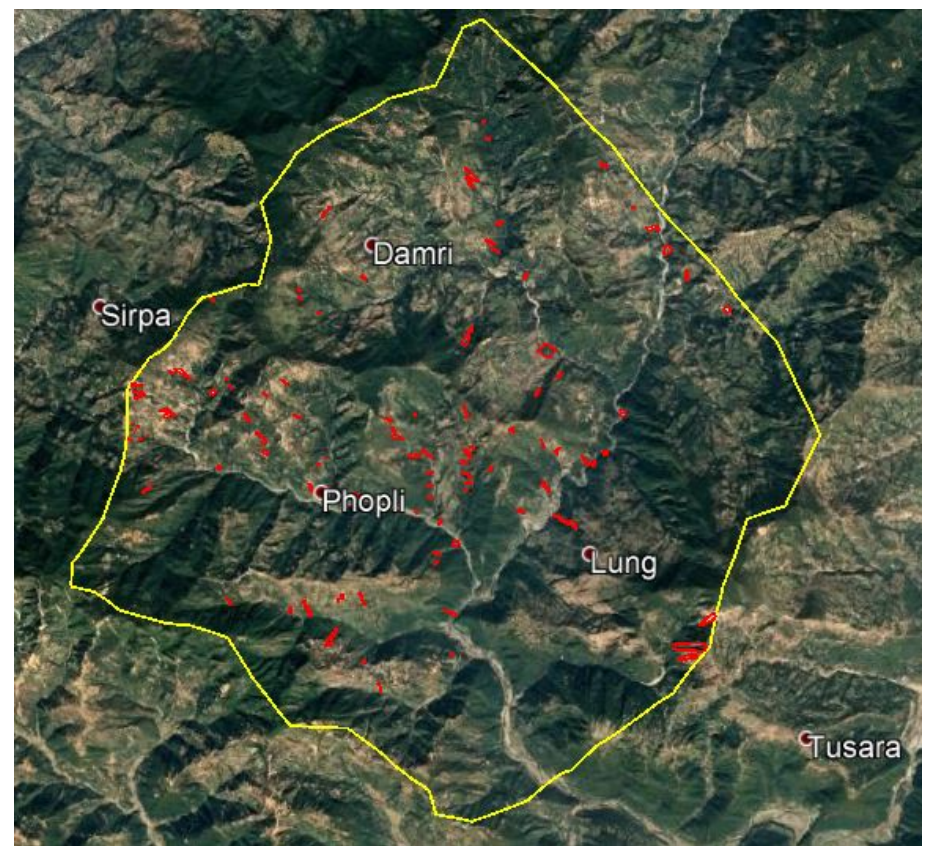

(b)

Figure 1. (a) Location map of Lung Khola catchment, Naubahini Rural Municipality, Pyuthan, Nepal; (b) Study area shown in Google Earth image.

Geographic Information System (GIS) is technologically capable of facilitating various functions of geospatial data handling, analysis and management. GIS technology was employed to model and predict landslide susceptibility (Dai \& Lee, 2002). Susceptibility mapping was done using Arc GIS. MS Excel was used for data analysis. The entire database for the study was extracted from Digital Elevation Model (DEM). Geological Map provided by Department of Mines and Geology, land cover map from ICIMOD and hydrological map was digitized from Google Earth imagery and road map from District administrative office, Pyuthan, Government of Nepal were used to obtain the necessary data for analysis (Table 1). The detail steps are shown in Figure 2. 
Table 1. Source, methods and tools used for the preparation of Landslide Susceptibility.

\begin{tabular}{|c|c|c|c|c|}
\hline S.N. & Factors & Category & Source & Tools Used \\
\hline 1. & Slope & & & \\
\hline $\begin{array}{l}2 . \\
3 .\end{array}$ & $\begin{array}{l}\text { Aspect } \\
\text { Plan and profile curvature }\end{array}$ & Geo-morphometric & $\begin{array}{l}\text { Extracted from DEM of cell-size } 12.5 \times 12.5 \text { and stored in } \\
\text { raster format of same cell size }\end{array}$ & $\begin{array}{l}\text { Surface tool } \\
\text { under Spatial analyst }\end{array}$ \\
\hline 4. & Elevation/contour & & & \\
\hline 5. & Land cover & Ground condition & Extracted from ICIMOD Landcover Map of Nepal (2010) & \\
\hline 6. & Geology & Ground condition & $\begin{array}{l}\text { Digitized and converted to raster format } \\
\text { of cell-size } 12.5 \times 12.5\end{array}$ & $\begin{array}{l}\text { Shapefiles were } \\
\text { created and digitized }\end{array}$ \\
\hline 7. & Distance from road & & $\begin{array}{l}\text { Extracted from OSM road map and converted to raster } \\
\text { format of cell-size } 12.5 \times 12.5\end{array}$ & $\begin{array}{l}\text { Euclidean distance tool under } \\
\text { distance of Spatial Analyst }\end{array}$ \\
\hline 8. & Distance from river & Dista & $\begin{array}{l}\text { Extracted from hydrology tool and converted to raster } \\
\text { format of cell-size } 12.5 \times 12.5\end{array}$ & $\begin{array}{l}\text { Hydrology tool and under } \\
\text { Spatial Analyst }\end{array}$ \\
\hline
\end{tabular}

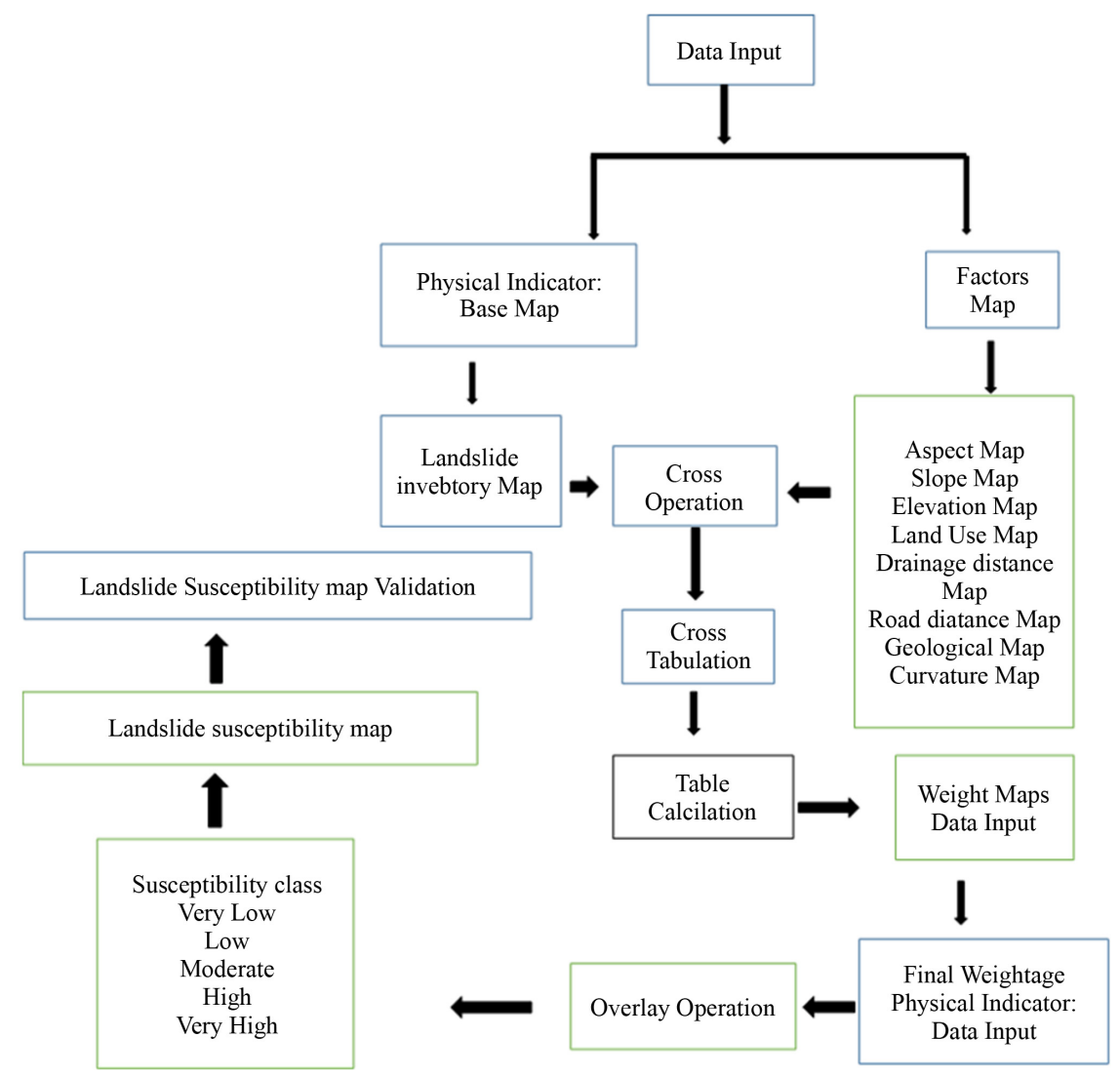

Figure 2. Flow chart shows the stepwise methods for landslide susceptibility mapping.

The weight of evidence model was used to combine dataset. The WOE method has been denoted mathematically by Regmi et al. (2010), and Van Westen et al. (2003). The present study calculated the weighted values for the classes of landslide-affected factors by using the following Equation (1) (Regmi et al., 2010). Calculation of each particular predictive variable a positive weight $\left(W^{\dagger}\right)$, when the event occurs and a negative weight $\left(W^{-}\right)$, when the event does not oc- 
cur. The weights are measures of correlation between evidence (predictive variable) and event, facts that make them easy to interpret in relation to empirical observation. Formulation based on density functions.

$$
\begin{aligned}
& W^{+}=\log _{e}\left\{A_{1} /\left(A_{1}+A_{2}\right) / A_{3} /\left(A_{3}+A_{4}\right)\right\} \\
& W^{-}=\log _{e}\left\{A_{2} /\left(A_{1}+A_{2}\right) / A_{4} /\left(A_{3}+A_{4}\right)\right\}
\end{aligned}
$$

where,

$A_{1}$ : is the number of the landslide pixels present on a given factor class;

$A_{2}$ : is the number of the landslide pixels not present in the given factor class;

$A_{3}$ : is the number of the pixels in the given factor class in which no landslide pixels are present;

$A_{4}$ : is the number of the pixels in which neither landslide nor the given factor is present.

$$
C=W^{+}-W^{-}
$$

The obtained difference between weights $(C)$ provides a measure of the strength of the correlation between the analyzed variable and landslides. Area under the curve (AUC) (Wahono, 2010; Pimiento, 2010) is used for model validation. The test landslides were used for success rate curve analysis which was obtained by plotting cumulative field landslide area percentage against the cumulative hazard value percentage.

\subsection{Model Validation}

Validation is a fundamental step in the development of susceptibility and prediction ability. The prediction of a landslide susceptibility model is usually estimated by using independent information. There are numbers of methods to validate such LSI map such as Receiver operating Characteristic (ROC) (Mathew et al., 2007; Yeon et al., 2010; Yilmaz, 2009) and Area under Curve methodology using Success rate curve. For above statistics area under the curve (AUC) (Wahono, 2010; Pimiento, 2010) is used for model validation. The test landslides were used for Success rate curve analysis which was obtained by plotting cumulative field landslide area percentage against the cumulative hazard value percentage.

\section{Results and Discussion}

The inventory showed 84 landslides having 293,797 $\mathrm{m}^{2}$ areas (Figure 3 ). In the area of $125.66 \mathrm{~km}^{2}$ the landslide density was found as 0.66 per sq. $\mathrm{km}$. The most landslides were concentrated in cultivated lands and areas devoid of vegetation or forest. The occurrence is higher in Phopli followed by Damri. Out of total 84 landslides, 59 landslides were used for train landslides and 25 landslides were used for test landslides. They were selected randomly representing the whole catchment. Landslides in the study area were found more in Phopli and Lung Khola area. Most of the landslide was found nearby road, river and forested area may be because of river cutting and loose deposit near river area whereas forests 


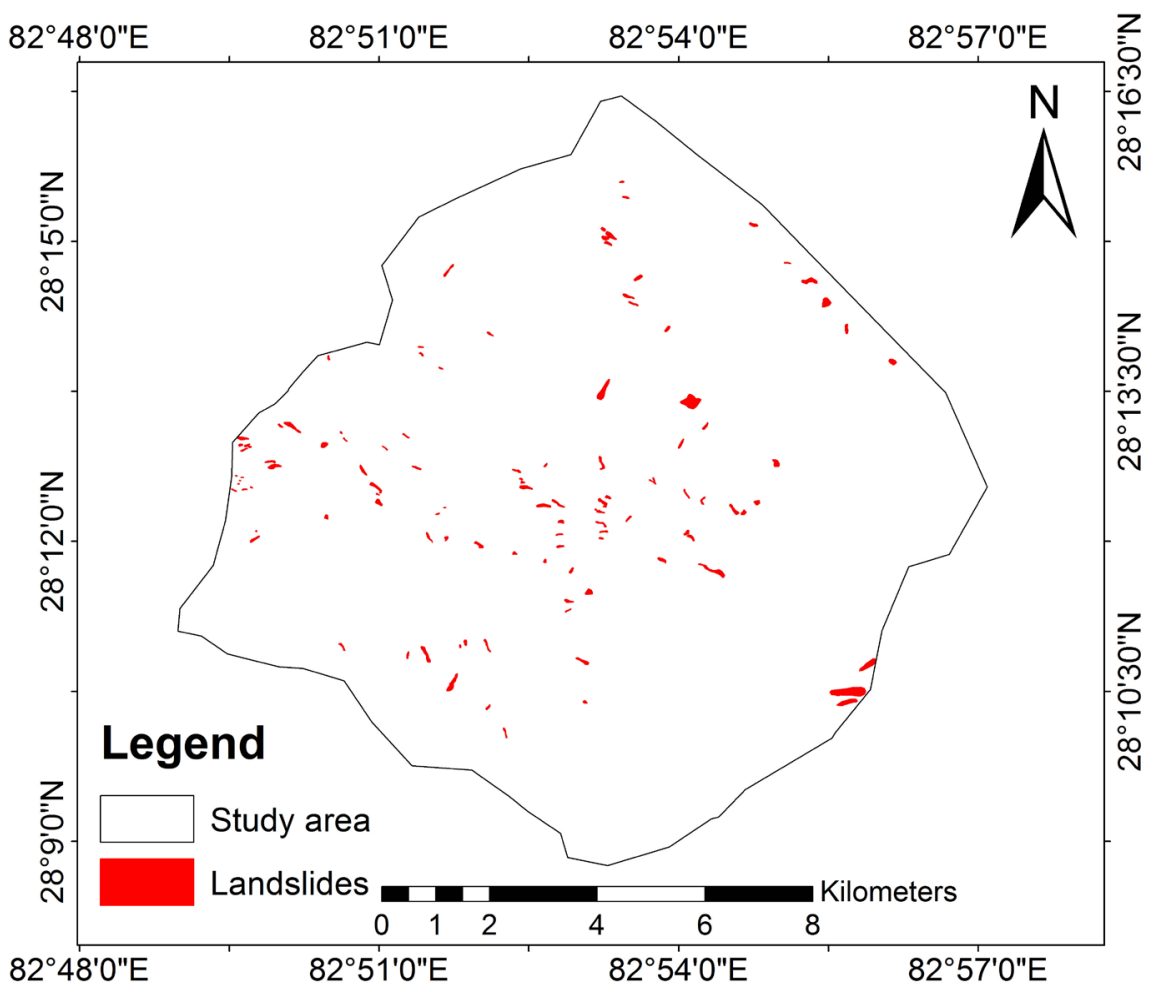

Figure 3. Landslide inventory map of study area.

are responsible factor for the anchoring of the soil. Zhang et al. (2016) also found that the areas with settlement and sparse forest more prone to landslide. Likewise the landslides were prone to the area facing southern slopes. Debris flows are major landslide problems in Nepal which are initiated at the gullies of hill tops in small catchments and flow down the high velocity (Dahal, Hasegawa, Bhandary, \& Yatabe, 2010). Anthropogenic factors like deforestation and the road building process, weak geology were also seen to be the cause of the landslide in the study area. Eight factor maps were prepared for landslide susceptibility mapping (Figure 4). Spatial relationship between landslide contributing factors and their weighted values are given in Table 2. Geologically, Robang phyllite and Malekhu limestone are found more potential for landslide. Elevation from $1500 \mathrm{~m}$ $1700 \mathrm{~m}$, east to south-east aspect, slope greater than $60^{\circ}, 50 \mathrm{~m}$ near from River, agriculture area and convex slope are more responsible for landslide (Table 2).

The Malekhu limestone and Robangphyllite are found more susceptible for landslide occurrence. Elevation between $1300 \mathrm{~m}$ and $1700 \mathrm{~m}$ are found more responsible for landslide.

Most of the land is covered by forest and agricultural area. All the settlement area is surrounded by cultivation land. Forest has occupied 47 percentage of the study area. Similarly cultivation land occupied 46 percentage of total land. The result showed that higher occurrences of landslides are in Agricultural land followed by forest. They accounted for $65.07 \%$ and $30.55 \%$ of total landslides respectively. After then Shrub land had occupied higher landslide area. Landslides 


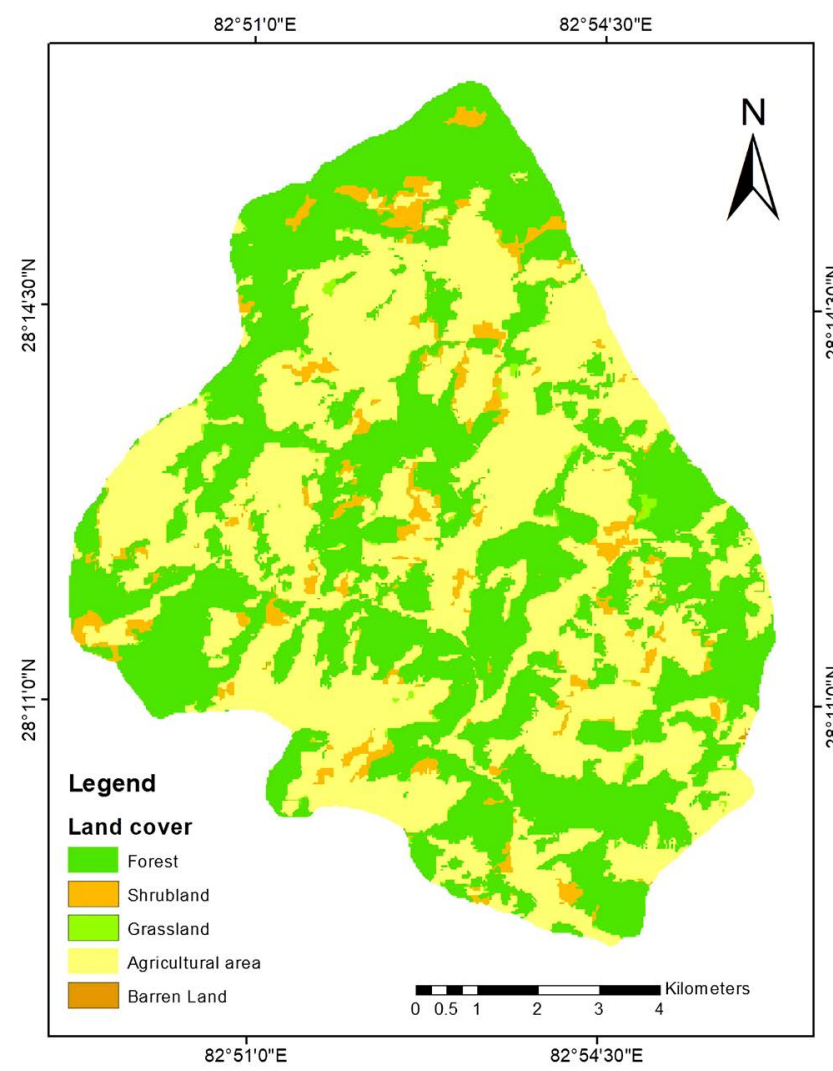

(a)

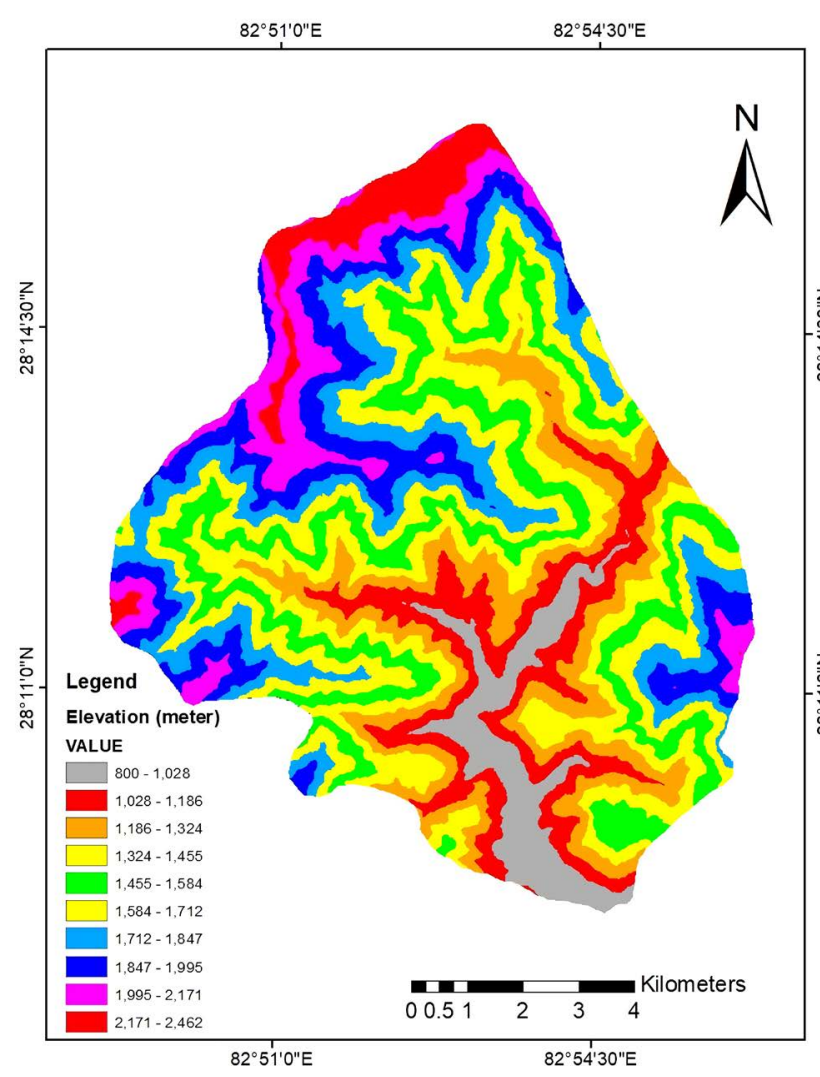

(c)

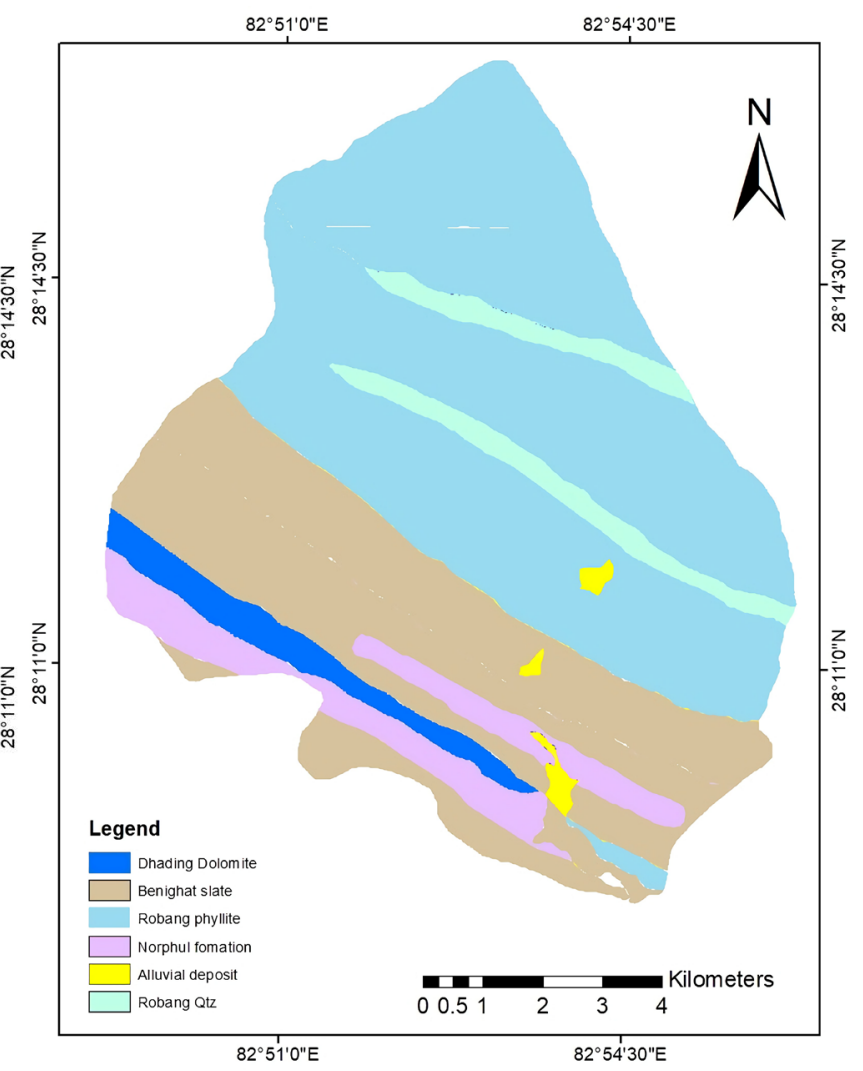

(b)

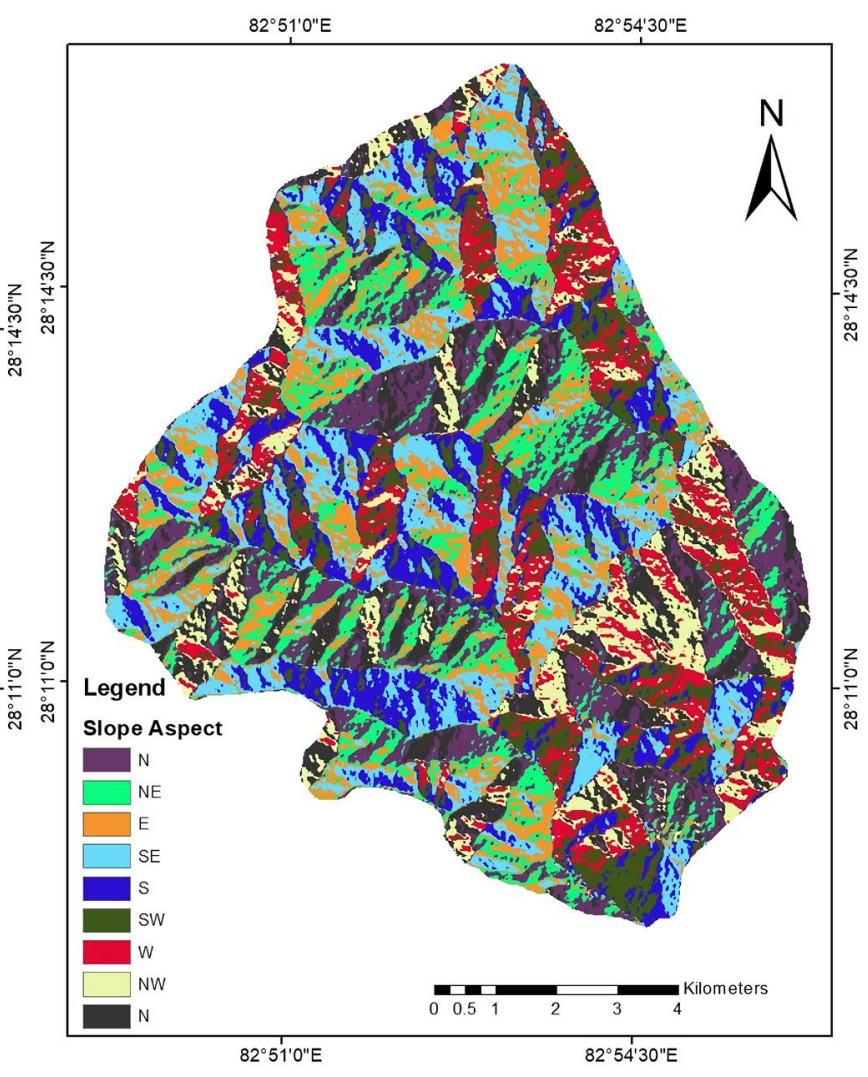

(d) 


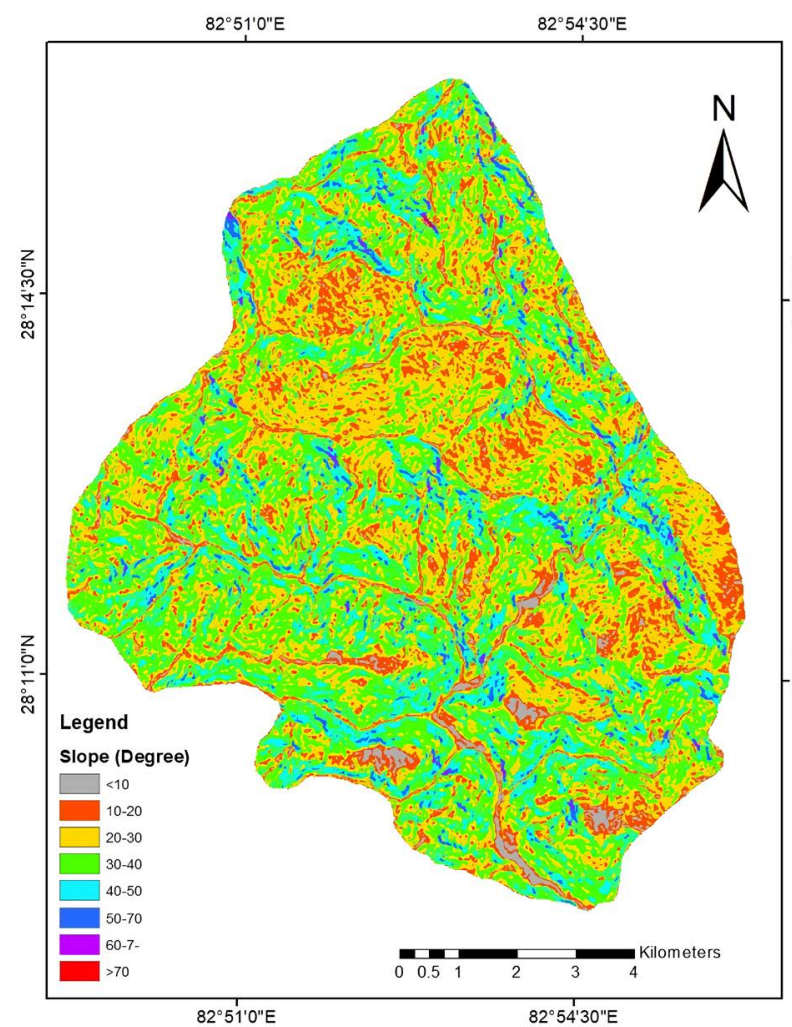

(e)

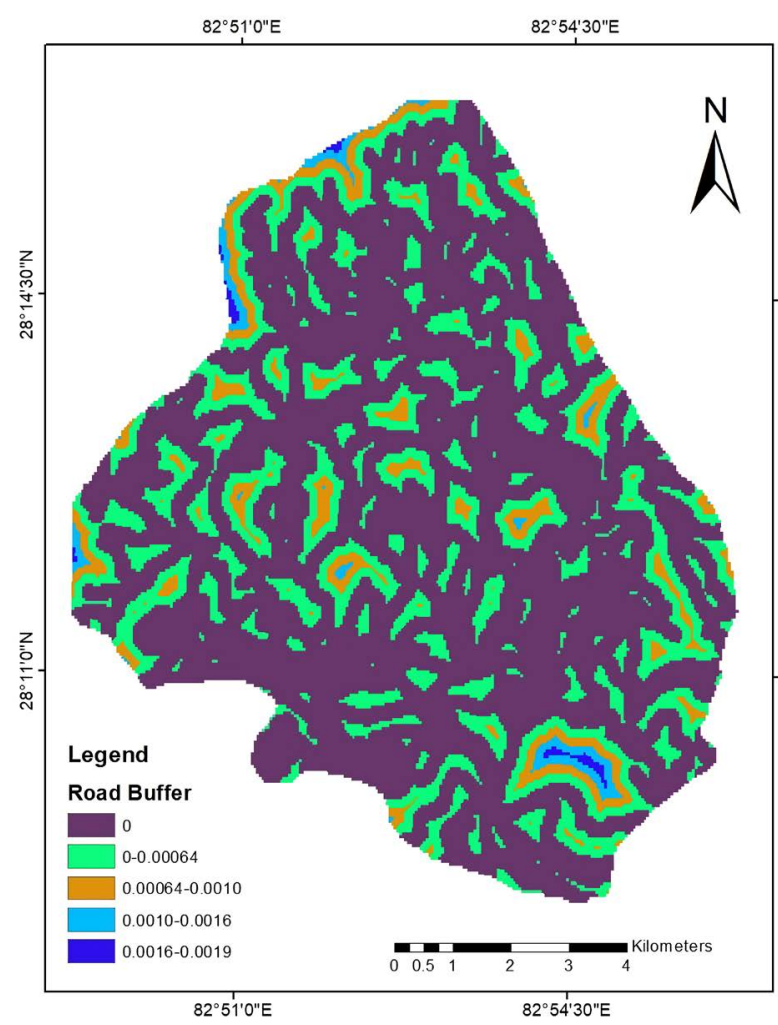

(d)

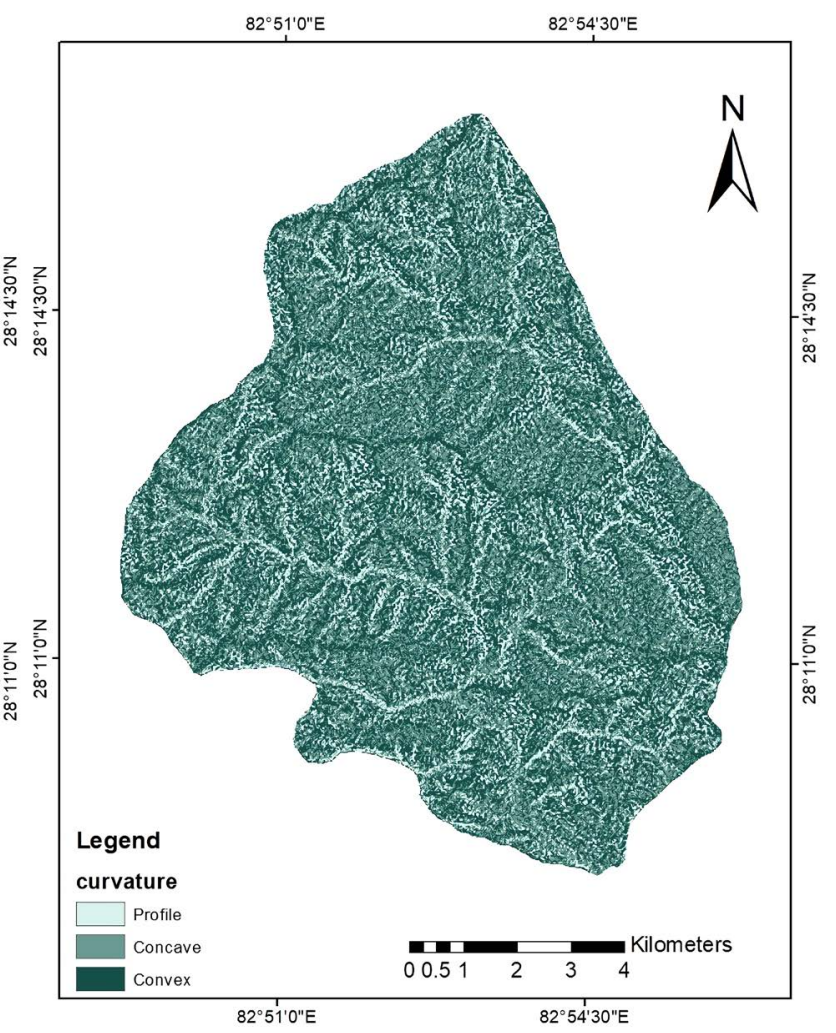

(f)

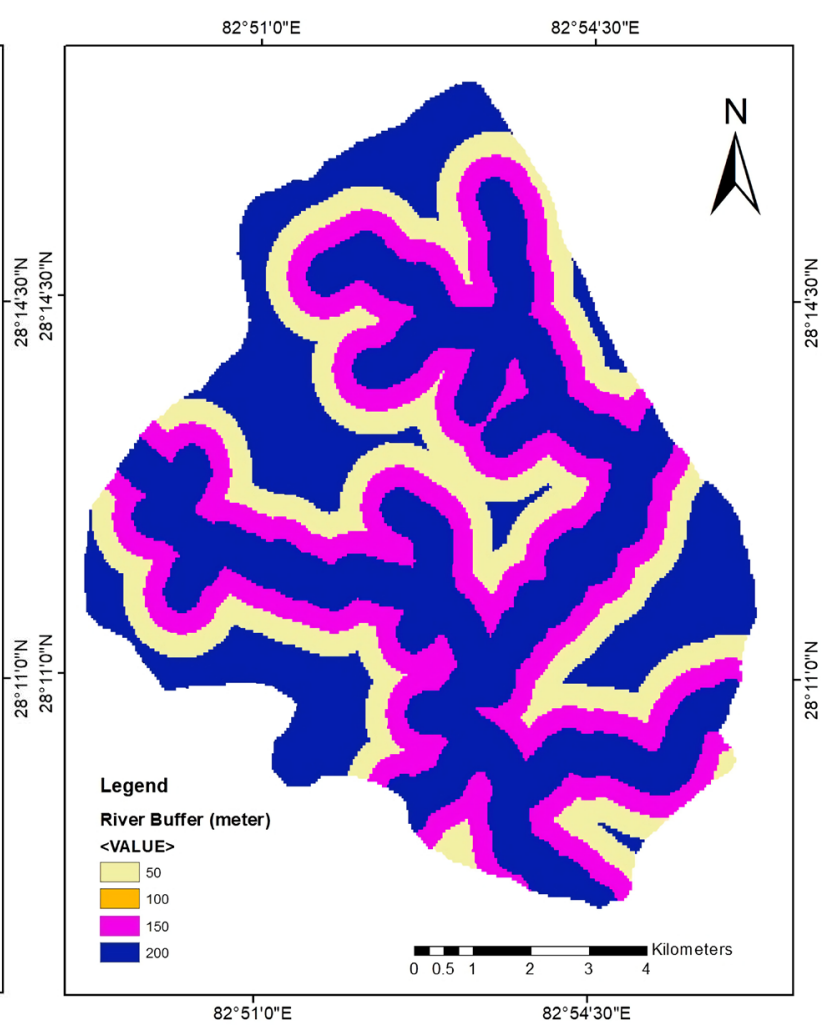

(h)

Figure 4. Topographic parameter maps of the study area; (a) land cover map (b) geological map (c) altitude (d) slope aspect (e) slope degree (f) plan curvature (g) road buffer $(\mathrm{h})$ river buffer. 
Table 2. Spatial relationship between each landslide conditioning factor and landslides extracted by using WoE model.

\begin{tabular}{|c|c|c|c|c|c|}
\hline Class_Name & $\begin{array}{l}\text { Percentage of Land } \\
\text { Cover Class }\end{array}$ & $\begin{array}{l}\text { Percentage of } \\
\text { Landslides }\end{array}$ & W_P & W_M & $\mathrm{C}$ \\
\hline \multicolumn{6}{|l|}{ Geology } \\
\hline Raduwa formation & 3.75 & 1.80 & -0.73 & 0.0201 & -0.753778932 \\
\hline Benighat slate & 29.55 & 24.82 & -0.17 & 0.065 & -0.23 \\
\hline Robangphyllite & 53.60 & 60.33 & 0.11 & -0.157 & 0.27 \\
\hline Alluvial deposit & 0.35 & 0.06 & -1.63 & 0.0029 & -1.63 \\
\hline Malekhu limestone & 0.38 & 4.43 & 2.47 & -0.042 & 2.514 \\
\hline \multicolumn{6}{|l|}{ Elevation } \\
\hline$(800-1028) \mathrm{m}$ & 0.0001 & 0 & 0 & 1.60 & 0 \\
\hline$(1028-1186) \mathrm{m}$ & 4.69 & 0 & 0 & 0.048 & 0 \\
\hline$(1186-1324) \mathrm{m}$ & 11.28 & 7.381 & -0.42 & 0.043 & -0.46 \\
\hline$(1324-1455) \mathrm{m}$ & 18.94 & 19.63 & 0.035 & -0.008 & 0.044 \\
\hline$(1455-1584) \mathrm{m}$ & 2.756 & 25.90 & 0.222 & -0.06 & 0.28 \\
\hline$(1584-1712) \mathrm{m}$ & 19.87 & 32.79 & 0.502 & -0.17 & 0.67 \\
\hline$(1712-1847) \mathrm{m}$ & 13.73 & 8.49 & -0.48 & 0.059 & -0.54 \\
\hline \multicolumn{6}{|l|}{ Aspect } \\
\hline$(-1-38) \mathrm{N}$ & 12.72 & 5.29 & -0.82 & 0.078 & -0.90 \\
\hline$(38-78) \mathrm{NE}$ & 11.60 & 9.95 & -0.09 & 0.012 & -0.11 \\
\hline$(78-117) \mathrm{E}$ & 12.06 & 24.58 & 0.76 & -0.17 & 0.94 \\
\hline$(117-155)$ SE & 13.47 & 26.74 & 0.74 & -0.18 & 0.92 \\
\hline$(155-195) S$ & 11.28 & 12.04 & 0.12 & -0.016 & 0.136 \\
\hline$(195-235)$ SW & 11.06 & 10.02 & -0.04 & 0.005 & -0.04 \\
\hline$(235-276) \mathrm{W}$ & 9.70 & 6.54 & -0.34 & 0.030 & -0.37 \\
\hline$(276-318) \mathrm{NW}$ & 8.16 & 2.01 & -1.34 & 0.063 & -1.40 \\
\hline \multicolumn{6}{|l|}{ Slope } \\
\hline $0-10$ & 0.92 & 0.22 & -1.55 & 0.027 & -1.58 \\
\hline $10-20$ & 4.22 & 3.714 & -0.16 & 0.027 & -0.18 \\
\hline $20-30$ & 7.53 & 7.228 & -0.07 & 0.027 & -0.10 \\
\hline $30-40$ & 10.8 & 10.74 & -0.04 & 0.027 & -0.06 \\
\hline $40-50$ & 14.1 & 14.25 & -0.02 & 0.027 & -0.05 \\
\hline $50-60$ & 17.46 & 17.77 & -0.01 & 0.027 & -0.04 \\
\hline $60-70$ & 20.77 & 21.28 & -0.008 & 0.027 & -0.03 \\
\hline \multicolumn{6}{|l|}{ Road distance } \\
\hline 0 & 63.74 & 68.26 & -0.30 & 0.014 & -0.32 \\
\hline $0-0.00065$ & 21.81 & 21.15 & -0.13 & 0.026 & -0.15 \\
\hline $0.0065-0.0010$ & 4.97 & 2.88 & 0.19 & -0.047 & 0.24 \\
\hline
\end{tabular}




\begin{tabular}{|c|c|c|c|c|c|}
\hline Continued & & & & & \\
\hline $0.0010-0.0014$ & 1.2 & 0 & -0.25 & 0.062 & -0.31 \\
\hline $0.0014-0.0016$ & 0.26 & 0 & 0.36 & -0.108 & 0.47 \\
\hline River distance & & & & & \\
\hline 50 & 31.08 & 39.83 & 0.12 & -0.75 & 0.88 \\
\hline 100 & 26.26 & 22.03 & -0.29 & 0.424 & -0.72 \\
\hline 150 & 20.89 & 15.25 & -0.43 & 0.342 & -0.77 \\
\hline 200 & 14.16 & 11.01 & -0.37 & 0.163 & -0.53 \\
\hline Land use & & & & & \\
\hline Forest & 47.45 & 30.55 & -0.441 & 0.27 & -0.72 \\
\hline Shrub land & 4.84 & 4.365 & -0.104 & 0.004 & -0.10 \\
\hline Grassland & 0.82 & 0 & 0 & 0.008 & 0 \\
\hline Agriculture area & 46.86 & 65.07 & 0.3293 & -0.42 & 0.74 \\
\hline Curvature & & & & & \\
\hline Profile & 98.87 & 98.88 & 0.0001 & -0.012 & 0.0131 \\
\hline Concave & 0.098 & 0.27 & 1.04 & -0.001 & 1.0442 \\
\hline Convex & 0.003 & 0.069 & 2.93 & -0.0006 & 2.9396 \\
\hline
\end{tabular}

were not observed in Grassland and Barren Area. Most of the landslide occurs at RobangPhyllite. Almost 60 percent of landslide occurred at this geology. The result is agreed with the field investigation. We observed maximum landslides in the agricultural land and RobangPhyllite. The final susceptibility map is shown in Figure 5. The susceptibility is divided into five different classes. $30.11 \mathrm{~km}^{2}$ areas are covered by highly susceptible class (Table 3 ) and the area of medium susceptible class is $24.21 \mathrm{~km}^{2}$. The area of very high susceptible class is 17.92 $\mathrm{km}^{2}$. The result shows that more than $70 \mathrm{~km}^{2}$ area is susceptible for landslide in this area.

For validity of LSM success rate curve was made and the landslide density of each class was calculated. The success rate curve constructed showed $73.16 \%$ of the study area lying under the curve (Figure 6).

Field observation showed steep slope angles, weak geology, rugged topography and groundwater were also responsible for the formation of landslide as major inherent reasons for landslides. Similar reasons were reported along with rainfall in Dumrebesi section of Narayanghat-Muglin road section by (Regmi et al., 2013). Elevation ranges from 800 meters to 2462 meters. Susceptibility was high for the altitude of 1300 to 1700 meters as shown by their positive weight values. Slope gradient is the most substantial cause of land sliding. Like slope, aspect is one of the important factors in preparing landslide susceptibility maps (Carrara et al., 1999). According to Martha et al. (2013) south facing slopes are known for their landslide proneness. Aspect maps were produced to show the relationship between aspect and landslides of the study. In this study, it is found 
Table 3. Landslide Density for five susceptibility classes.

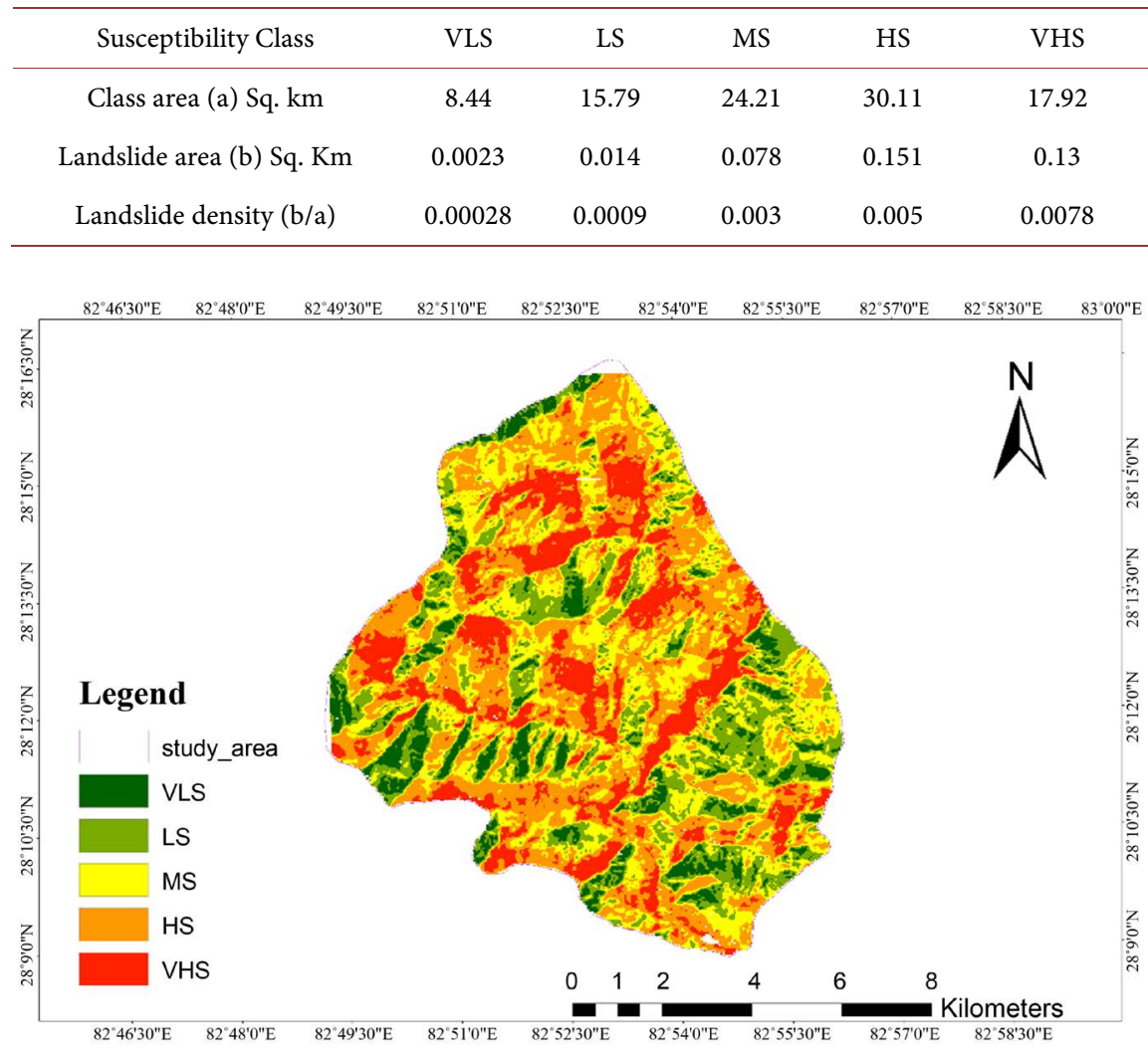

Figure 5. Landslide susceptibility map of study area.

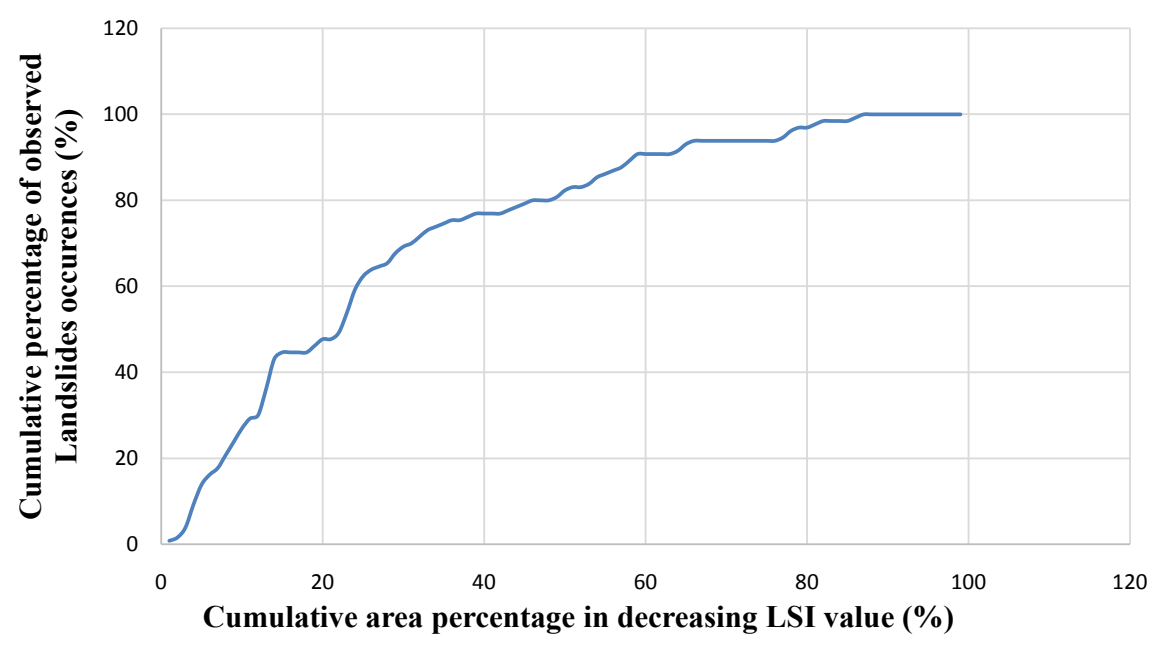

Figure 6. Success rate curve of landslide susceptibility model validation.

that geology, River (drainage), elevation, land use and curvature are found major responsible factor for landslide susceptibility.

\section{Conclusion}

In conclusion, we mapped 84 landslide polygons from Google earth and by field verification. Most of the landslides were observed to be concentrated along the 
Phoply and Lung Khola area. Landslide occurrence exhibits the correlation with slope angle, aspect, elevation, geology, drainage and geological structures. Slope greater than $60^{\circ}$, south east and south aspect, elevation greater than $1300 \mathrm{~m}$, Malekhu limestone and Robangphyllite are found more susceptible for landslide occurrence. The susceptibility is divided in to five different classes. $30.11 \mathrm{~km}^{2}$ areas are covered by highly susceptible class and the area of medium susceptible class is $24.21 \mathrm{~km}^{2}$. The area of very high susceptible class is $17.92 \mathrm{~km}^{2}$. The result shows that more than $70 \mathrm{~km}^{2}$ area is susceptible for landslide in this area

The validation results showed that the success rate curve with 73.16 percentage of the area lying under the curve indicating that prediction ability of the Weight of Evidence model. These landslide susceptibility maps can be used as a planning tool by prioritizing areas for controlling the landslide effects. More than $73 \%$ success rate indicates that Weight of Evidence model is suitable model for the landslide susceptibility in the study area.

\section{Acknowledgements}

We want to acknowledge the people of Naubahini rural municipality for their help and cooperation during our field study. We are also thankful to Central District office and District Police office of Pyuthan district for providing permission of study and security during field study.

\section{Conflicts of Interest}

The authors declare no conflicts of interest regarding the publication of this paper.

\section{References}

Baum, R. L., Godt, J. W., \& Savage, W. Z. (2010). Estimating the Timing and Location of Shallow Rainfall-Induced Landslides Using a Model for Transient, Unsaturated Infiltration. Journal of Geophysical Research, 115. https://doi.org/10.1029/2009JF001321

Baum, R. L., Savage, W. Z., \& Godt, J. W. (2002). TRIGRS - A Fortran Program for Transient Rainfall Infiltration and Grid-Based Regional Slope-Stability Analysis (p. 38). US Geological Survey Open-File Report 2002-424. https://doi.org/10.3133/ofr02424

Bhandari, B. P., \& Dhakal, S. (2018). Lithological Control on Landslide in the BabaiKhola Watershed, Siwaliks Zone of Nepal. American Journal of Earth Sciences, 5, 54-64.

Bonham-Carter, G. F. (1994). Geographic Information Systems for Geoscientists-Modeling with GIS. Computer Methods in the Geoscientists, 13, 398.

Brabb, E. E. (1985). Innovative Approaches to Landslide Hazard and Risk Mapping. In International Landslide Symposium Proceedings (Vol. 1, pp. 17-22). Tokyo: Japan Landslide Society.

Carrara, A., Guzzetti, F., Cardinali, M., \& Reichenbach, P. (1999) Use of GIS Technology in the Prediction and Monitoring of Landslide Hazard. Natural Hazards, 20, 117-135. https://doi.org/10.1023/A:1008097111310

Crosta, G. B., \& Frattini, P. (2003). Distributed Modelling of Shallow Landslides Triggered by Intense Rainfall. Natural Hazards and Earth System Science, 3, 81-93. 
https://doi.org/10.5194/nhess-3-81-2003

Dahal., R. K., Hasegawa, S., Bhandary, N. P., \& Yatabe, R. (2010). Low-Cost Road for the Development of Nepal and Its Engineering Geological Consequences. In Geologically Active, Proceedings of the 11th IAEG Congress (Vol. 5, No. 10, pp. 4085-4094). Tokyo, Japan.

Dahal., R. K., Hasegawa, S., Bhandary, N. P., Poudel, P. P., Nonomura, A., \& Yatabe, R. (2012). A Replication of Landslide Hazard Mapping at Catchment Scale. Geomatics, Natural Hazards and Risk, 3, 161-192. https://doi.org/10.1080/19475705.2011.629007

Dai, F. C., \& Lee, C. F. (2002). Landslide Characteristics and Slope Instability Modeling Using GIS, Lantau Island, Hong Kong. Geomorphology, 42, 213-228.

https://doi.org/10.1016/S0169-555X(01)00087-3

DMG (2006). Geological Map of Part of Rolpa, Pyuthan and Arghakhanchi District. Kathmandu: Department of Mines and Geology.

Guzzetti, F., Cardinali, M., Reichenbach, P., \& Carrara, A. (2000). Comparing Landslide Maps: A Case Study in the Upper Tiber River Basin, Centrally Italy. Environmental Management, 25, 247-363. https://doi.org/10.1007/s002679910020

Guzzetti, F., Reichenbach, P., Cardinali, M., Galli, M., \& Ardizzone, F. (2005). Landslide Hazard Assessment in the Staffora Basin, Northern Italian Apennines. Geomorphology, 72, 272-299. https://doi.org/10.1016/j.geomorph.2005.06.002

ICIMOD (2010). Landcover of Nepal 2010. Kathmandu: ICIMOD.

Laban, P (1979). Landslide Occurrence in Nepal. Food and Agriculture Organization, Government of Nepal, Ministry of Forest, Soil and Water Conservation, UNDP, Kathmandu, p. 30.

Laban, P. (1979). Integrated Watershed Management Torrent Control and Land Use Development Project. Landslide Occurrence in Nepal.

Lepore, C., Arnone, E., Noto, L. V., Sivandran, G., \& Bras, R. L. (2013). Physically Based Modeling of Rainfall-Triggered Landslides: A Case Study in the Luquillo Forest, Puerto Rico. Hydrology and Earth System Sciences, 17, 3371-3387. https://doi.org/10.5194/hessd-10-1333-2013

Martha, T., van Westen, C., Kerle, N., Jetten, V., \& Vinod Kumar, K. (2013) Landslide Hazard and Risk Assessment Using Semi-Automatically Created Landslide Inventories. Geomorphology, 184, 139-150. https://doi.org/10.1016/j.geomorph.2012.12.001

Mathew, J., Jha, V., \& Rawat, G. (2007). Weights of Evidence Modelling for Landslide Hazard Zonation Mapping in Part of Bhagirathi Valley, Uttarakhand. Current Science, 92, 628-638.

Pimiento, E. (2010). Shallow Landslide Susceptibility; Modeling and Validation. Doctoral Dissertation, Master Thesis, Lund: Lund University.

Regmi, A. D., Devkota, K. C., Pourghasemi, H. R., Yoshidam K., Pradhan, B., Ryu, I. C., Dhital, M.R., \& Althuwaynee, O. F. (2013). Landslide Susceptibility Mapping Using Certainty Factor, Index of Entropy and Logistic Regression Models in GIS and Their Comparison at Mugling-Narayanghat Road Section in Nepal Himalaya. Natural Hazards, 65, 135-165. https://doi.org/10.1007/s11069-012-0347-6

Regmi, N. R., Giardino, J. R., \& Vitek, J. D. (2010). Modeling Susceptibility to Landslides Using the Weight of Evidence Approach: Western Colorado, USA. Geomorphology, 115, 172-187. https://doi.org/10.1016/j.geomorph.2009.10.002

Rossi, G., Catani, F., Leoni, L., Segoni, S., \& Tofani, V. (2013). HIRESSS: A Physically Based Slope Stability Simulator for HPC Applications. Natural Hazards and Earth System Sciences, 13, 151-166. https://doi.org/10.5194/nhess-13-151-2013 
Upreti, B. N. (2001). The Physiographic and Geology of Nepal and Their Bearing on the Landslide Problem. In T. C. Li, S. R. Chalise, \& B. N. Upreti (Eds.), Landslide Hazard Mitigation in the Hindu Kush-Himalaya (pp. 31-49). Kathmandu: International Centre for Integrated Mountain Development.

Van Westen, C. J., Rengers, N., \& Soeters, R. (2003). Use of Geomorphological Information in Indirect Landslide Susceptibility Assessment. Natural Hazards, 30, 399-419. https://doi.org/10.1023/B:NHAZ.0000007097.42735.9e

Varnes, D. J. (1978). Slope Movement Types and Processes. Special Report, 176, 11-33.

Wahono, B. F. D. (2010). Applications of Statistical and Heuristic Methods for Landslide Susceptibility Assessments. Unpublished Technical Report, Yogyakarta: Gadjah Mada University and International Institute for Geo-Information Science and Earth Observation.

Yeon, Y. K., Han, J. G., \& Ryu, K. H. (2010). Landslide Susceptibility Mapping in Injae, Korea, Using a Decision Tree. Engineering Geology, 116, 274-283. https://doi.org/10.1016/j.enggeo.2010.09.009

Yilmaz, I. (2009). Landslide Susceptibility Mapping Using Frequency Ratio, Logistic Regression, Artificial Neural Networks and Their Comparison: A Case Study from Kat Landslides (Tokat-Turkey). Computers \& Geosciences, 35, 1125-1138.

https://doi.org/10.1016/j.cageo.2008.08.007

Zhang, G., Cai, Y., Zheng, Z., Zhen, J., Liu, Y., \& Huang, K. (2016). Integration of the Statistical Index Method and the Analytic Hierarchy Process Technique for the Assessment of Landslide Susceptibility in Huizhou, China. Catena, 142, 233-244.

https://doi.org/10.1016/j.catena.2016.03.028 